\title{
Importance of blood smear in the distinction of hemoparasites: A case report of anaplasmosis
}

\author{
Importância do esfregaço de sangue na distinção de hemoparasitas: Um relatório do caso da \\ anaplasmose
}

\author{
Fábio Darlan Bernardo, Fagner Luiz da Costa Freitas², Adolfo Firmino da Silva-Neto ${ }^{3}$, \\ Carina Franciscato ${ }^{3} *$ \\ ${ }^{1}$ Universidade Federal da Fronteira Sul (UFFS), Realeza, Paraná, Brazil. E- \\ mail: fabiobernardo104@gmail.com \\ ${ }^{2}$ Universidade Federal da Fronteira Sul (UFFS), Realeza, E-mail: fagner.freitas@uffs.edu.br \\ ${ }^{3}$ Universidade Federal de Juiz de Fora (UFJF), E-mail: adolfo.neto@ufjf.edu.br \\ ${ }^{3}$ Departamento de Medicina Veterinária, Universidade Federal de Juiz de Fora (UFJF), Rua José \\ Lourenço Kelmer, s/n Campus Universitário, Bairro São Pedro, Juiz de Fora - MG 36.036-900, Brazil. \\ Corresponding author.Email address: carinafranciscato@yahoo.com.br
}

\begin{abstract}
This study describes the clinical case of a Jersey female calf, 5 months-old, naturally infected by Anaplasma marginale, from a dairy farm in Salto do Lontra city (Southwest of Paraná State, Brazil). The animal showed clinical signs suggesting haemoparasitosis, determining icteric mucous membranes, increased heart and respiratory rates and $41,2^{\circ} \mathrm{C}$ of body temperature. Laboratory examination demonstrated the presence of A. marginale in the blood smear, $12 \%$ of parasitaemia, normochromic and normocytic anaemia, leukocytosis by monocytosis and lymphocytosis, gamma glutamyl transferase serum elevation, decrease of serum total protein and albumin, and the increase of total bilirubin serum levels due to the elevation of indirect bilirubin. This study reports the first case of A. marginale identified in the Laboratory for Veterinary Clinical Analysis at Universidade Federal da Fronteira Sul (UFFS), Campus Realeza - PR (a new University in the region), highlighting the importance of blood smear in order to identify and discriminate agents causing Complex Bovine Parasitic Sadness.
\end{abstract}

Keywords: Anaplasmosis; blood smear; biochemical tests; haemogram; parasitaemia.

Resumo: O presente trabalho descreve o caso de uma bezerra, da raça Jersey de cinco meses de idade, naturalmente infectada por Anaplasma marginale, pertencente a uma propriedade leiteira do Município de Salto do Lontra (Sudoeste do Paraná). O animal apresentou sinais clínicos sugestivos de hemoparasitose, constatandose mucosas ictéricas, aumento da frequência cardíaca e respiratória, além de temperatura corporal de $41,2^{\circ} \mathrm{C}$. Os exames laboratoriais revelaram a presença de A. marginale no esfregaço sanguíneo, parasitemia de $12 \%$, anemia normocítica normocrômica, leucocitose por monocitose e linfocitose, elevação sérica da Gama Glutamil Transferase, diminuição sérica de proteína totais e albumina, além do aumento dos níveis séricos de bilirrubina total devido ao aumento bilirrubina indireta. Este trabalho relata o primeiro caso de A. marginale identificado no Laboratório de Análises Clínicas Veterinárias da Universidade Federal da Fronteira Sul (UFFS), Campus Realeza-PR (uma nova Universidade da região), destacando a importância do esfregaço sanguíneo na identificação e diferenciação dos agentes causadores da Tristeza Parasitária Bovina.

Palavras-chave: Anaplasmose; esfregaço sanguíneo; exames bioquímicos; hemograma; parasitemia.

Autor para correspondência. Email address: * carinafranciscato@yahoo.com.br

Recebido em 4.2.2016. Aceito em 10.6.2016

http://dx.doi.org/10.5935/1981-2965.20160024 
Bernardo et al., Revista Brasileira de Higiene e Sanidade Animal (v.10, n.2) p. 290 - 296, abr - jun (2016)

\section{Introduction}

Anaplasma marginale is from Anaplasmataceae family and Rickettsiales order. It is classified as an obligate intraerythrocytic hemoparasite (Aubry and Geale, 2011) causing the destruction of the red blood cells by stimulating extravascular hemolysis which is mediated by monocytes, so causing hemolytic anaemia and jaundice. This parasite is one of the agents of Complex Bovine Parasitic Sadness, disease what presents significant morbidity and mortality, which can also be caused by Babesia bovis and B. Bigemina protozoa (FARIAS, 2007). However, the treatment is different for each of these agents. So it is very important to distinguish between them.

Anaplasmosis and babesiosis clinical signs are due hemolytic anaemia, thus, the animal can show pale or icteric mucous membrane, fever, dehydration and anorexia in either case. On the other hand, the anaplasmosis pathogenesis courses with the extravascular destruction of parasitized erythrocytes, whereas in the babesiosis, the red cell can be destroyed intravascularly or removed by the splenic macrophages (extravascularly) (JAIN, 1993).
This report has as objective to record the finding of Anaplasma marginale in a blood smear from a naturally infected Jersey female calf, 5 months-old, besides to show its hematologic alterations and biochemical complications, as a means of understanding disease clinical signs and pathogenicity. This study reports the first case of $A$. marginale identified in the Laboratory for Veterinary Clinical Analysis at Universidade Federal da Fronteira Sul (UFFS), Campus Realeza PR (a new University in the region), highlighting the importance of blood smear in order to identify and discriminate agents causing Complex Bovine Parasitic Sadness.

\section{Case Report}

It is related a case of a naturally infected Jersey female calf, 5 monthsold, from a dairy farm in Salto do Lontra city (Southwest of Paraná State, Brazil) showing clinical signs suggesting haemoparasitosis, apathy, anorexia, in sternal decubitus position, hyperthermia, $41,2^{\circ} \mathrm{C}$ of rectal temperature, icteric conjunctiva and vaginal mucous membranes, and higher heart and respiratory rates: $110 \mathrm{bpm}$ and $60 \mathrm{mpm}$, respectively. Blood samples were collected by venous puncture and 
sent to Laboratory for Veterinary

Clinical Analysis at UFFS in order to perform haemogram, biochemical tests and hemoparasites research.

During the microscopic exam of the blood smear (Diff quick stain), it was observed red blood cells containing little dark spots in peripheral location in line with the intraerythrocytic bodies formed by Rickettsia (Figure 1), this way confirming the infection of the calf by $A$. marginale. This animal showed $12 \%$ of parasitaemia.

Red blood cells count (Table 1) showed reduction in erythrocytes number, hemoglobin values and hematocrit, in line with severe anaemia (normochromic and normocytic). On the other hand, leucogram (Table 1) showed an increase of the total leukocyte number due to the increase of lymphocytes and monocytes. Biochemical tests (Table 1) demonstrated elevation of gamma glutamyl transferase (GGT) serum while Aspartate Aminotransferase (AST) remained in normal level; decreasing of serum total protein and albumin, and the increasing of total bilirubin serum levels due to the elevation of indirect bilirubin. Values for urea and creatinine were as per the standard description for the species.

Table 1. Haematological and biochemical parameters of calf naturally infected by Anaplasma marginale.

\begin{tabular}{lcc}
\hline \multicolumn{1}{c}{ Parameters } & Results & Reference Values \\
\hline Erythrocytes & 2,94 & $5-10(\mathrm{x} 106 / \mu \mathrm{l})^{\mathrm{a}}$ \\
Hemoglobin & 4,3 & $8-15(\mathrm{~g} / \mathrm{dl})^{\mathrm{a}}$ \\
Hematocrit & 13,4 & $24-46(\%)^{\mathrm{a}}$ \\
MCV $^{1}$ & 45,6 & $40-60(\mathrm{fL})^{\mathrm{a}}$ \\
MCHC $^{2}$ & 32,1 & $30-36(\%)^{\mathrm{a}}$ \\
Total Leukocytes & 13300 & $4.000-12.000 / \mu \mathrm{L}^{\mathrm{a}}$ \\
Lymphocytes & 10241 & $2.500-7.500 / \mu \mathrm{L}^{\mathrm{a}}$ \\
Neutrophils & 1463 & $600-4.000 / \mu \mathrm{L}^{\mathrm{a}}$ \\
Monocytes & 1463 & $25-840 / \mu \mathrm{L}^{\mathrm{a}}$ \\
Eosinophils & 133 & $0-2.400 / \mu \mathrm{L}^{\mathrm{a}}$ \\
AST & 50 & $48-100(\mathrm{UI} / \mathrm{L})^{\mathrm{a}}$ \\
GGT & 27 & $6,1-17,4(\mathrm{UI} / \mathrm{L})^{\mathrm{b}}$ \\
Albumin & 2,3 & $3,03-3,55(\mathrm{~g} / \mathrm{dl})^{\mathrm{b}}$ \\
Total Protein & 6 & $6,7-7,4(\mathrm{~g} / \mathrm{dl})^{\mathrm{b}}$ \\
Total Bilirubin & 2,6 & $0,01-0,5(\mathrm{mg} / \mathrm{dl})^{\mathrm{b}}$ \\
Direct Bilirubin & 0,32 & $0,04-0,44(\mathrm{mg} / \mathrm{dl})^{\mathrm{b}}$ \\
Indirect Bilirubin & 2,28 & $0-0,3(\mathrm{mg} / \mathrm{dl})^{\mathrm{b}}$ \\
Blood Urea Nitrogen & 26 & $20-30(\mathrm{mg} / \mathrm{dl})^{\mathrm{b}}$ \\
Creatinine & 0,94 & $1-2(\mathrm{mg} / \mathrm{dl})^{\mathrm{b}}$ \\
\hline
\end{tabular}

${ }^{1}$ Mean corpuscular volume. ${ }^{2}$ Mean corpuscular hemoglobin concentration.

${ }^{\mathrm{a}}$ Meyer e Harvey (1998), ${ }^{\mathrm{b}}$ Kaneko et al. (1997) 


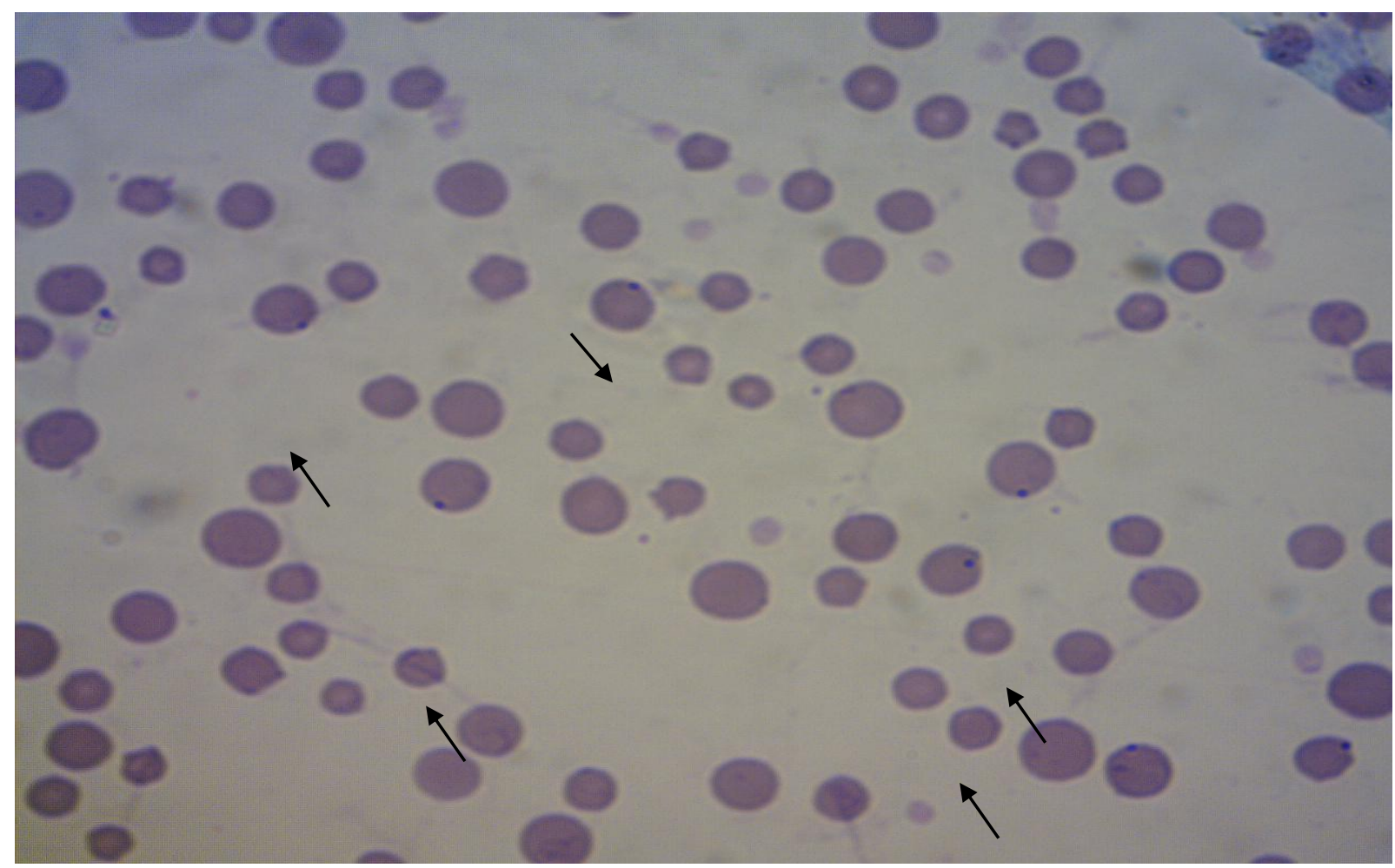

Figure. 1. Blood smear of calf showing intraerythrocytic bodies befitting with Anaplasma marginale (arrows). Moreover, it is observed anisocytosis and polychromasia.

The animal was treated with oxytetracycline (single dose, $20 \mathrm{mg} / \mathrm{kg}$, intramuscularly, and another dose three days after) and with diminazene aceturate (single dose, 3,5mg/kg, intramuscularly). The calf responded well to the treatment, showing better clinical signs.

\section{Discussion}

Researches have demonstrated anaplasmosis clinical signs are observed after parasitaemia exceeds 15\% (Radostits et al., 2007), and during the acute phase of the disease, parasitaemia can vary from $15 \%$ to $48 \%$ (ALFONSO et al., 1996). However, the animal studied in this report showed $12 \%$ of parasitaemia, just enough to cause severe anaemia and the development of anaplasmosis clinical signs.

Additionally, some authors have related that this disease is more frequent and more serious in animals over six months-old (KOCAN et al., 2003). But, in this case, the animal was younger and showed a severe clinical sign of haemoparasitosis.

Thus, the severity of anaemia with parasitaemia less than $15 \%$ and the disease development in an animal under six monthsold could be associated to the failure in 
Bernardo et al., Revista Brasileira de Higiene e Sanidade Animal (v.10, n.2) p. 290 - 296, abr - jun (2016)

colostrum feeding to the calf, as reported by the farm owner. So, it is possible to affirm the lack of passive immunity against the hemoparasite, which could be obtained through colostrum feeding, affected the health of the calf.

It is known that anaplasmosis causes anaemia in bovine (Gonçalves et al., 2005), but in this case is highlighted its acute severity. The more red blood cells are affected, the more extensive their damage by extravascular haemolysis (Farias, 2007) and the higher tissue hypoxia (Welzl et al., 2001), which explain clinical signs of tachycardia and tachypnea. Anaemia showed by the animal, characterized as normochromic and normocytic, does not correspond to regenerative anaemia (macrocytic and hypochromic) found in haemoparasitosis (SULAIMAN et al., 2010; ESMAEILNEJAD et al., 2012). The significant increase of infected red blood cells associated to quick phagocytosis and the very short time between the beginning of the damage and the testing accomplishment, which could not be enough for bone marrow replaces new red cells in blood circulation, can justify the type of anaemia found in this study.

Leukocytosis by monocytosis and lymphocytosis was already reported in small ruminants infected by Babesia sp (Sulaiman et al., 2010; Esmaeilnejad et al., 2012), where macrophages activated by the hemoparasite release pro-inflammatory cytokines as Interleukin-1 (IL-1), Interleukin-12 (IL-12) and Tumor Necrosis Factor (TNF) (Hemmer et al., 2000), which are important activators of polymorphonuclear and mononuclear cells in bone marrow. Equal stimulation mechanism can be triggered by Anaplasma marginale since its pathogenesis also involves macrophages activation.

Total bilirubin increasing occurred due to the elevation of indirect bilirubin, which can be explained by the immune-mediated mechanism of anaemia caused by Anaplasma marginale, where macrophages, mainly from spleen and liver, perform erytrophagocytosis causing extravascular hemolysis with the increase of indirect bilirubin production and the release of that metabolite in blood circulation.

That fact explains the jaundice presented by the animal, because serum values of bilirubin above $2,0 \mathrm{mg} / \mathrm{dL}$ are enough to give rise to yellowish skin and mucous membranes (KANEKO et al., 1997).

This jaundice can be classified as prehepatic through the mechanism described previously. Results of gamma glutamyl transferase (GGT) serum elevation are according to Gonçalves et al. (2005), thus 
Bernardo et al., Revista Brasileira de Higiene e Sanidade Animal (v.10, n.2) p. 290 - 296, abr - jun (2016)

showing a cholestatic disorder responsible for GGT overflow to blood.

Total protein and albumin reduction can characterize digestive disorder, fever or lower food intake, as observed by Sulaiman et al. (2010) in their research with small ruminants infected by hemoparasites. It is highlighted that fever $\left(41,2^{\circ} \mathrm{C}\right)$ and lower food intake were observed in the present study.

The treatment of the calf was performed before Anaplasma marginale diagnosis, thus it was applied oxytetracycline and diminazene aceturate to it. However, data obtained in this study showed that the laboratory diagnosis of hemoparasites through blood smear analysis is able to discriminate agents causing Complex Bovine Parasitic Sadness, which can avoid the use of unnecessary drugs to treat animals.

\section{Conclusion}

Anaplasma marginale diagnosis can be done through blood smear test, so making possible the discrimination of agents causing Complex Bovine Parasitic Sadness. In addition, parasitaemia and red blood cell parameters suggest anaemia severity, while alteration in white blood cells parameters can explain inflammatory activation mechanism triggered by the parasite.

\section{References}

1.ALFONSO, J.; MEDINA, R.; FAZZINO, F.; CABALLERO, $\mathrm{H}$. Clinical and hematological change in calves infected with Anaplasma marginale. Acta Científica Venezolana, v.47 .n.1, p.50-57, 1996.

2. AUBRY, P.; GEALE, D.W. A Review of Bovine Anaplasmosis. Transboundary Emerging Diseases, v.58, p.1-30, 2011.

3.ESMAEILNEJAD, B.; TAVASSOLI, M.; ASRI-REZAEI, S. Investigation of hematological and biochemical parameters in small ruminants naturally infected with Babesia ovis. Veterinary Research Fórum, v.3, n.1, p.31-36, 2012.

4.FARIAS, N.A. Tristeza Parasitária Bovina. In: RIET-CORREA F. (ed) Doenças de Ruminantes e Eqüídeos, 3rd edn. Pallotti, Santa Maria, p.524-532, 2007.

5.GONÇALVES, R.C.; SILVA, D.P.G.; CHIACCHIO, S.B.; BORGES, A.S.; AMORIM, R.M.; BANDARRA, E.P.; TAKAHIRA, R.K. Anaplasmose Neonatal em bezerro. Veterinária Notícias, v.11, n.1, p.95-98, 2005.

6.HEMMER, R.M.; FERRICK, D.A.; CONRAD, P.A. Role of T cells and cytokines in fatal and resoliving experimental babesiosis: protection in TNFRp55-1-mice infected with the human Babesia WAI parasite. Journal of Parasitology, v.86, n.4, p.736-742, 2000.

7.JAIN, N.C. Essentials of veterinary hematology. 1 ed. Philadelphia: Lea \& Febiger, 1993, $417 \mathrm{p}$.

8.KANEKO, J.J.; HARVEY, D.W.; BRUSS, W.L. Clinical biochemistry of domestic animals. Academic Press, San Diego, 1997, $932 \mathrm{p}$. 
9.KOCAN, K.M.; FUENTE, J.; GUGLIELMONE, A.A.; MELÉNDEZ, R.D. Antigens and alternatives for control of Anaplasma marginale infection in cattle. Clinical Microbiology Reviews, v.16, n.4, p.698-712, 2003.

10.MEYER, D.J.; HARVEY, J.W. Veterinary Laboratory Medicine: Interpretation and Diagnosis. W.B. Saunders, Philadelphia, 1998, 372 p.

11.RADOSTITS， O.M.; GAY， C.C.; HINCHCLIFF, K.W.; CONSTABLE, P.D. Veterinary Medicine: A Textbook of the Diseases of Cattle, Horses, Sheep, Pigs and Goats. $10^{\text {th }}$ ed. Saunders, USA. 2007, 2156p.

12.SULAIMAN, E.G.; ARSLAN, S.H.; ALlOBAIDI, Q.T.; DAHAM, E. Clinical, haematological and biochemical studies of babesiosis in native goats in Mosul. Iraq Journal of Veterinary Sciences, v.24, n.1, p.31-35, 2010.

13.WELZL, C.; LEISEWITZ, A.L.; JACOBSON, L.S.; VAUGHAN-SCOTTA, T.; MYBURGHA, E. Systemic inflammatory response syndrome and multiple-organ damage/dysfunction in complicated canine babesiosis. Journal of South African Veterinary Association, v.72, n.3, p.158162, 2001. 